\title{
Modification of 80-100 penetration grade bitumen
}

\author{
S. K. Ray*, R. H. Bhuiyan, M. S. Islam, M. J. Abedin, P. K. Nandy, Z. Islam, M. R. Hasan and H. P. Nur
}

Fibre and Polymer Research Division, Bangladesh Council of Scientific and Industrial Research, Dhaka-1205, Bangladesh

Received: 11 January 2019

Revised: 01 April 2019

Accepted: 06 May 2019

DOI: https://doi.org/10.3329/bjsir.v54i4.44565

\begin{abstract}
Bangladesh is facing severe problem in using 80-100 penetration grade bitumen for flexible pavement construction due to its high temperature susceptibility, e.g. lower penetration index, insufficient viscosity and lower moisture resistance. To improve these properties bitumen modification is essential. Present work describes the modification of general 80-100 penetration grade bitumen by incorporating natural rubber latex and an organic polymeric additive, polyaniline. Mixing parameters, such as amounts of natural rubber and polyaniline, mixing time and temperature and stirring speed were controlled and investigated carefully. Six bituminous aggregate binders were prepared by varying amounts of natural rubber latex into bitumen by wet process. Physical tests, e.g. penetration, softening point, ductility and viscosity were performed on all samples and compared with unmodified base bitumen. Modified bitumen samples showed better properties compared to ordinary 80-100 penetration grade bitumen. Spectral, thermal and scanning electron microscopic tests were performed on control and bitumen-natural rubber-polyaniline blend samples. Result showed better mixing efficiency of the constituents and thus improved physical, thermal and anti-stripping properties suitable for paving application in Bangladesh and like countries. All findings were discussed in details.
\end{abstract}

Keywords: Bitumen; Natural rubber latex; Polyaniline; Anti-stripping agent; Penetration index; Flexible pavement construction

\section{Introduction}

Bitumen, as an aggregate binder, is being produced to meet a variety of specifications based upon physical properties suitable for paving application. Construction of flexible pavement is usually done with conventional penetration grade bitumen that is prone to premature failures due to cracks and rutting (Shafabakhsh, 2014; Smith, 2004). Bituminous pavement requires frequent maintenance due to heavy rainfall and variation of seasonal temperature (Willway, et al. 2008; Žilinjtơ et al. 2016; Fwa, 1987). The high costs involved in the road maintenance has created interest on asphalt modifications. Modified bitumen has been used in Europe and some Asian countries for durable pavement construction (Ibeagia et al. 2012; Pyshyev et al. 2016).

The roadway condition of Bangladesh has reached in a critical stage because of hot weather condition (Afroz and Jabin, 2017). Their work suggested the use of harder and less temperature susceptible bitumen for flexible pavement construction. These types of bitumen can be found from low penetration and high viscosity grade bitumen. Natural rubber modification of bitumen can satisfy the mentioned properties (Pristi, 2013).

Over the last several decades, many researchers have taken initiatives to modify bitumen by adding a wide range of materials to ensure pavement durability. Different types of polymers, rubbers, etc. have been used with bitumen but their effect was mainly to increase bitumen viscosity (Read and Whiteoak, 2003; Becker et al. 2011). A lot of studies were also conducted on the use of natural rubber as latex or powdered form. In some studies, natural rubber had been used in a vulcanized state, e.g. tyre crumb, but this was difficult to disperse in bitumen (Pristi, 2013; Ragab et al. 2016; Subhy et al. 2016; Azahar et al. 2016; Rossi et al. 2017). Rubber modified bitumen is being evaluated as a

\footnotetext{
*Corresponding author e-mail: swapanray_bcsir@ymail.com
} 
promising binder with improved pavement performances, e.g. greater resistance towards rutting and thermal cracking and decrease fatigue damage, striping and temperature susceptibility (Fernando and Nadarajah, 1969). Typically, rubber modified bitumen are more viscous compared to unmodified bitumen and tent to improve adhesive bonding to the aggregate particles. Rubberized bitumen showed excellent durability of pavement in terms of cracking and aging resistances. Increased skid resistance and lower tire noise also provides safety and quicker ride to the users. The life cycle cost of the pavement is lower compared to ordinary bitumen (Mashaan et al., 2014).

Adhesion between aggregates and bitumen may be improved by the addition of anti-stripping agents, which change the interfacial conditions between aggregate and bitumen (Rossi et al., 2017; Cui et al., 2014). Generally, 0.1 to $1.0 \%$ fatty amines are commonly used as anti-stripping additive to improve the adhesion. It is believed that the amine groups are attracted to the surface of aggregates whilst the fatty groups remain in the bitumen. The result is an ionically bonded cross-link between aggregate and bitumen (Read and Whiteoak, 2003).

On the other hand, addition of antioxidant can significantly mitigate the bitumen hardening or aging affects (Dessouky et al., 2015). Bitumen hardening is occurred by the presence of oxygen, ultraviolet radiation and by changes in temperature, resulting in a decrease in penetration, an increase in softening point and usually, an increase in penetration index (Yener and Hinıslıoğlu, 2014; Read and Whiteoak, 2003). Bitumen should not be excessively hardened during hot storage or asphalt manufacturing process or in service on the road. To reduce excessive hardening, different types of antioxidants e.g. amines, phenols, organo-zinc, organo-lead compounds, etc. were used and the anti-aging properties were evaluated (Petersen, 2009). Secondary aromatic amines are the most effective anti-oxidants, antiozonant and metal ion deactivator. As a secondary aromatic amine, polyaniline requires more attention as a potential anti-oxidant for bitumen modification.

Polyaniline was used as an antioxidant for plastic and rubber vulcanizates to improve anti-aging and mechanical properties (El-Ghaffar et al., 2014; Zailan et al., 2017). As the polyaniline in its emeraldine salt form contains positively charged secondary nitrogen atom in long polymer chain, it may act as an anti-stripping agent like fatty amines and thus improve adhesion between aggregates and modified bitumen. Polyaniline was reported may be for the first time as an additive in bitumen modification for its synergistic effects as a polymeric antioxidant and anti-striping agent. So far no report is available on polyaniline for bitumen modification.

The aim of this research work is to modify general penetration grade bitumen by natural rubber latex and polyaniline and to evaluate the physical properties of modified bitumen suitable for paving application. The synergistic effects of polyaniline as a potential antioxidant and anti-stripping agent for bitumen modification need to be explored.

\section{Materials and methods}

Ammonia stabilized natural rubber latex (solid content 60\%) was collected from Ramu Rubber Garden, Cox's bazer, Bangladesh. Bitumen (penetration grade 80-100; softening point $44 \pm 1^{\circ} \mathrm{C}$ ) was collected from Eastern Refinery Limited, Bangladesh Petroleum Corporation, Bangladesh. Laboratory synthesized thermally stable polyaniline emeraldine salt (PANI-ES) of particle size 1-2 micron was used as an antioxidant and anti-stripping agent for bitumen. All materials used in this experiment were of reagent grades.

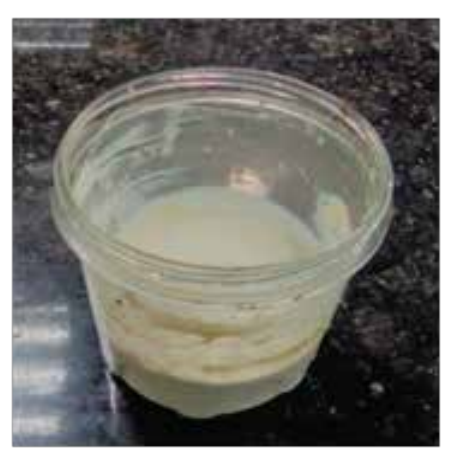

Natural rubber latex

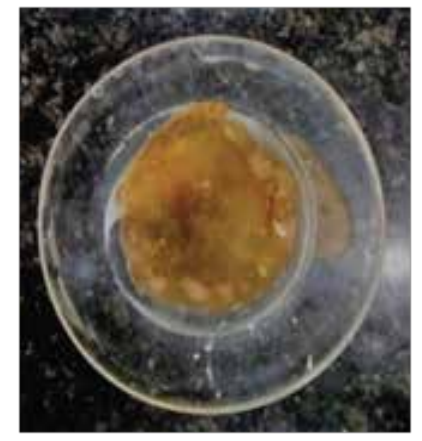

Dried natural rubber
Fig. 1. Natural rubber latex and its dried form

\section{Preparation of bitumen-natural rubber-polyaniline blend}

Bitumen-natural rubber-polyaniline samples were prepared by blending natural rubber latex with bitumen in presence of $1 \%$ (by weight of bitumen) polyanilene emeraldine salt. 


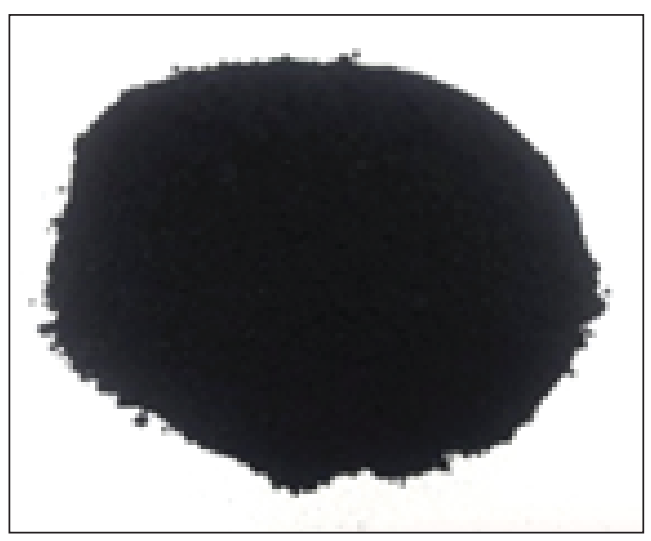

Synthesized PANI-ES

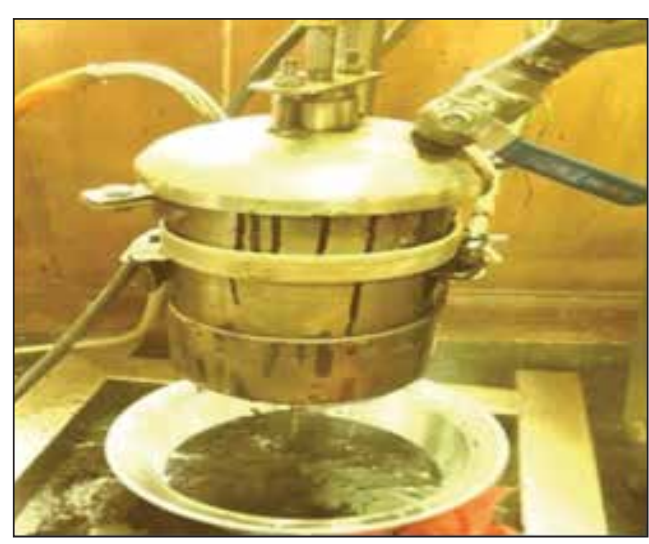

Bitumen modification unit

Fig. 2. Synthesized polyaniline emeraldine salt and bitumen modification unit

Table I. Preparation of bitumen-natural rubber-polyaniline blends

\begin{tabular}{ccccccc}
\hline $\begin{array}{c}\text { Sample } \\
\text { No }\end{array}$ & $\begin{array}{c}\text { Amount of } \\
\text { bitumen }(\mathrm{g})\end{array}$ & $\begin{array}{c}\text { Amount of } \\
\text { natural rubber } \\
\text { w/w\% of } \\
\text { bitumen })\end{array}$ & $\begin{array}{c}\text { Polyaniline- } \\
\text { ES } \\
(\mathrm{w} / \mathrm{w} \% \text { of } \\
\text { bitumen })\end{array}$ & $\begin{array}{c}\text { Temp. } \\
\left({ }^{\circ} \mathrm{C}\right)\end{array}$ & $\begin{array}{c}\text { Stirring } \\
\text { speed } \\
(\mathrm{rpm})\end{array}$ & $\begin{array}{c}\text { Time } \\
(\mathrm{Min})\end{array}$ \\
\hline B-1 & 0 & 0 & & & \\
\hline B-2 & 1 & & & & \\
B-3 & & 3 & 1.0 & & & \\
B-4 & $1000 \pm 5$ & 5 & & & & \\
B-5 & & 7 & & & & \\
B-6 & 9 & 12 & & & \\
B-7 & & 12 & & & \\
\hline
\end{tabular}

Mixing parameters, such as percentages of natural rubber, amount of polyanilene emeraldine salt, time, temperature, and stirring speed were controlled carefully to prepare homogeneous blends. Six samples (B-2 to B-7) were prepared by adding $1,3,5,7,9$ and $12 \%$ natural rubber with bitumen. Evolved ammonia gas from latex addition was absorbed in water for reuse. The blends were cooled at room temperature for $48 \mathrm{hrs}$ and then preserved for further analysis. Experimental details have been given in Table I.

\section{Characterization of bitumen-natural rubber-polyaniline blends}

Base 80-100 penetration grade bitumen and prepared bitumen-natural rubber-polyaniline blends were characterized by standard methods.

\section{Softening point}

Softening point of the samples was determined according to ASTM D 36-95 using Softening point test apparatus (brand: Koehler Instrument, USA; model: K42090). Results have been presented in Fig. 1(a).

\section{Penetration}

Penetration value of the samples was determined according to ASTM D 05-06 using digital penetrometer (Anton-Paar, Type-PNR-12, P/N: 146375, Austria). Results have been presented in Fig. 1(a).

\section{Ductility}

Ductility of the samples was determined according to ASDM D 113-99 by using ductility tester (brand: Shamvabi, India). Results have been presented in Fig. 1(a). 


\section{Rotational viscosity}

Flow curves of the prepared sample were constructed by taking necessary amount in CC 27 cup of Rotational Rheometer (Brand: Anton-Paar, Model: RheolabQC; Spindle CC27). Considering asphalt mixing temperature $135^{\circ} \mathrm{C}$ and compaction temperature $90^{\circ} \mathrm{C}$, viscosities were measured at these temperatures applying variable shear rate from $10 \mathrm{~s}^{-1}$ to $100 \mathrm{~s}^{-1}$. Results have been presented in Fig. 2.

\section{Fourier transformed mid-infrared (FT-MIR) spectroscopy}

Fourier transformed mid-infrared (FT-MIR) spectroscopy was performed using a Perkin-Elmer Fourier Transform Infrared Spectrometer equipped with a diamond attenuated total reflaction accessory (Frontier, Perkin-Elmer, UK; Software: Spectrum version 10.4.4). The spectral range was $600-4,000 \mathrm{~cm}^{-1}$ at a spectral resolution of $4 \mathrm{~cm}^{-1}$. Results have been presented in Fig. 3 .

\section{Scanning electron microscopy}

Field emission scanning electron microscope (brand: JEOL, Japan; model: JSM-761OF) was employed to observe surface micrographs of 80-100 penetration grade bitumen and bitumen-natural rubber-polyaniline blends at different resolutions to evaluate mixing or dispersion properties. SEM images have been presented in Fig. 4.

\section{Thermal analysis}

Thermal analyses of 80-100 penetration grade bitumen and selected bitumen-natural rubber-polyaniline blend were performed using Simultaneous Thermal Analyzer (brand: Netzsch, Germany; model: JupiterF3; Software: Proteous). The instrument simultaneously measured the sample's weight change and the energy input required for keeping the sample and reference material at the same temperature as a function of temperature. In order to elucidate the physicochemical properties, $10 \mathrm{mg}$ of each sample was introduced for measurement under nitrogen atmosphere $(50 \mathrm{ml} / \mathrm{min})$ at a heating rate of $10^{\circ} \mathrm{C} / \mathrm{min}$ from $30^{\circ} \mathrm{C}$ to $950^{\circ} \mathrm{C}$ (Sensor used: S-type; Furnace used: Silicon carbide). TG-DSC thermograms have been presented in Fig. 5.

\section{Results and discussions}

\section{Properties of rubberized bitumen}

Six bituminous binders were prepared by varying amounts of natural rubber into bitumen by wet process. In all cases, $1 \%$ polyaniline as emeraldine salt form (by weight of bitumen) was used. It was observed that the physical properties of modified bitumen were improved compared to base 80-100 penetration grade bitumen (B-1).

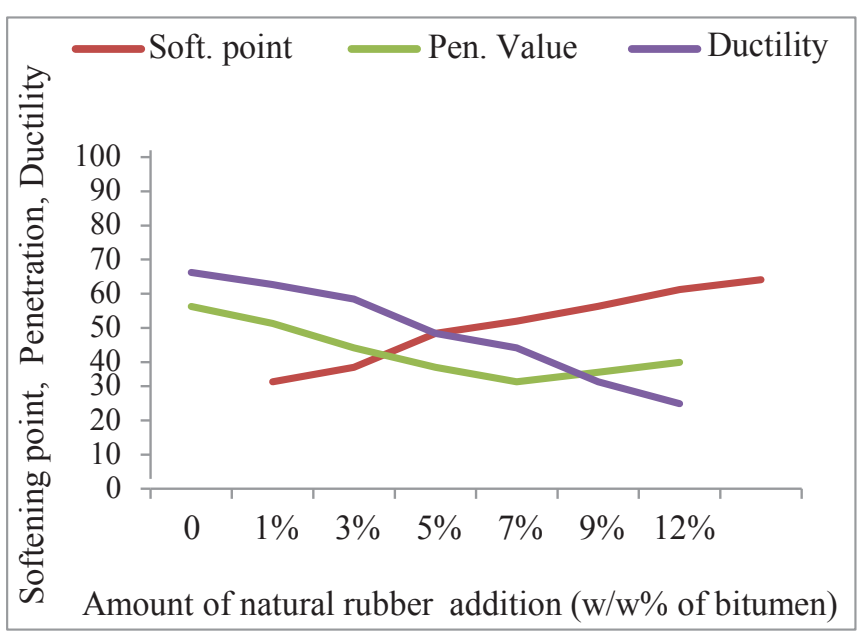

Fig. 1(a). Physical properties of bitumen-natural rubberpolyaniline blend

Softening point

The softening point is important property generally used to determine the consistency of bitumen. Higher softening point, as an indicator of stiffening effect, is favorable since bitumen with higher softening point may be less susceptible to permanent deformation or rutting (Mashaan et al., 2014). It was observed from Fig. 1(a) that the softening point of the modified bitumen samples gradually increased from $44^{\circ} \mathrm{C}$ to $86^{\circ} \mathrm{C}$ with increasing natural rubber percentages from 1 to $12 \%$ in presence of $1 \%$ polyaniline emeraldine salt. Similar trends of increasing viscosity were observed in the modification of bitumen using different types of latex (Fernando and Nadarajah, 1969). 3\% natural rubber latex (by weight of bitumen) modified bitumen may be considered for paving application due to its appreciable softening point for warmer regions like Bangladesh.

\section{Penetration test}

Penetration test at $25^{\circ} \mathrm{C}$ was performed on bitumen samples for grading the material in terms of hardness. Average penetration value of unmodified $80-100$ penetration grade bitumen was $80\left(1 / 10^{\text {th }} \mathrm{mm}\right)$. Modification result showed that the penetration values of prepared sample were decreased with increasing amount of natural rubber latex upto $7(\mathrm{w} / \mathrm{w}) \%$ of bitumen and then increased upto $12(\mathrm{w} / \mathrm{w})$ $\%$ of natural rubber latex addition. It was due to incompatibility of natural rubber latex to be dispersed with base bitumen at higher percentages. Addition of $3(\mathrm{w} / \mathrm{w}) \%$ 
natural rubber latex showed penetration value of $58\left(1 / 10^{\text {th }}\right.$ $\mathrm{mm}$ ) which was comparable to conventional $60-70$ penetration grade bitumen as recommended in Bangladesh for paving application (Afroz and Jabin, 2017). Panetration value of $81\left(1 / 10^{\text {th }} \mathrm{mm}\right)$ was reported by modifying $80-100$ bitumen with $3(\mathrm{w} / \mathrm{w}) \%$ natural rubber latex. No additives, e.g. anti-stripping agent or anti-oxidant were used in this study (Shafii et al., 2017).

Penetration indices of the sample were determined using following equation (Read and Whiteoak, 2003) and presented in figure $1(\mathrm{~b})$.

$$
\mathrm{PI}=\frac{1952-500 \log \text { pen }-20 \mathrm{SP}}{50 \log \text { pen }-\mathrm{SP}-120}
$$

Penetration index of bitumen should be in the range from -3 to +5 . Generally the paving bitumen is characterized by penetration range from +2 to -2 . If the penetration index is less than -2 , then the bitumen behaves more Newtonian and become very brittle at low temperature. Bitumen of high penetration index shows time-dependent elastic properties and provides improved resistance to permanent deformation.

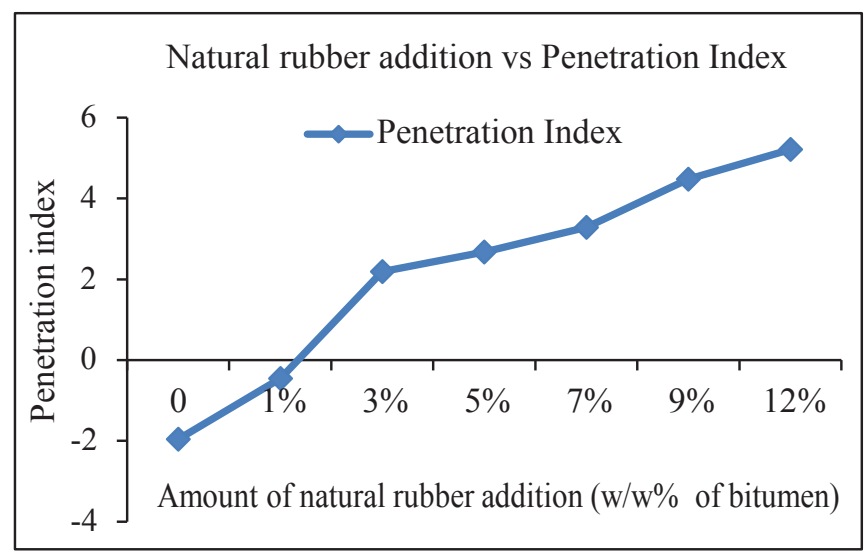

Fig. 1(b). Change of penetration index with natural rubber latex addition

As shown in Fig. 1(b), penetration indices of prepared samples increased from -1.96 to 5.21 with increased amount of natural rubber in presence of $1 \%$ polyaniline emeraldine salt. 3(w/w) \% natural rubber modified bitumen showed optimal penetration index, 2.19 and may be considered for paving application in Bangladesh or like countries where road temperature increased gradually due to climate change. In another study, 3(w/w) \% natural rubber latex was blended with 80-100 penetration grade bitumen that showed penetration index of -0.796 (Shafii et al., 2017). Optimum conditions for the maximum PI of 3.72 were reported using
70-100 grade bitumen and tire rubber at the mixing temperature of $150^{\circ} \mathrm{C}$, mixing time of 120 minute, tire rubber content of $10 \%$ and mixing speed of $250 \mathrm{rpm}$ (Hınıslığlu, 2011).

\section{Ductility}

Ductility is the opposite of brittleness behavior of materials. It is the property of materials that permit to undergo deformation or elongation. It expresses the extent to which the material can be plastically deformed without fracture. From figure 1(a) it was observed that the ductility of prepared bituminous binders was decreased with increased amount of natural rubber to base bitumen. This trend was also observed in other works on bitumen modification by natural rubber latex or crumb rubber (Fernando and Nadarajah, 1969; Mashaan et al., 2011). Among the prepared samples, 3 (w/w) $\%$ of natural rubber modified bitumen with $1 \%$ polyaniline emeraldine salt showed appreciable ductility, e.g. $78 \mathrm{~cm}$ for paving application (Read and Whiteoak, 2003; Krishnapriya, 2015; Kishore and Gottala, 2015).

\section{Rotational viscosity}

Dynamic viscosity of the samples were measured at application temperatures, e.g. $90^{\circ} \mathrm{C}$ as compaction and $135^{\circ} \mathrm{C}$ as mixing temperatures applying variable shear rate and showed greater values compared to base 80-100 penetration grade bitumen. It was observed that the samples showed shear rate depended viscosity and the viscosity decreased with increasing shear rate at $90^{\circ} \mathrm{C}$ and $135^{\circ} \mathrm{C}$, e.g. non-newtonian shear thinning behavior. This behavior was shown due to structural reorganization or alignment of the fluid molecules due to flow. For all samples, viscosity decreased as the temperature increased from $90^{\circ} \mathrm{C}$ to $135^{\circ} \mathrm{C}$ (Remišová et al., 2016). The test of dynamic viscosity is considered as a fundamental test that indicates the ability of bitumen to coat the aggregates properly. The value of dynamic viscosity depends on shear rate, molecular weight distribution, filler, temperature and additives, etc.

Dynamic viscosity was increased with increasing amount of natural rubber latex upto $12(\mathrm{w} / \mathrm{w}) \%$ of bitumen. This percentage was the maximum as set for the experiment. At mixing temperature, optimal viscosity of bitumen should be greater than $0.2 \mathrm{~Pa}$.s for proper coating of the aggregates. For effective compaction to take place, the viscosity of the bitumen should be between 5.0 Pa.s and 30 Pa.s. At viscosities lower than 5 Pa.s, the material will probably be 

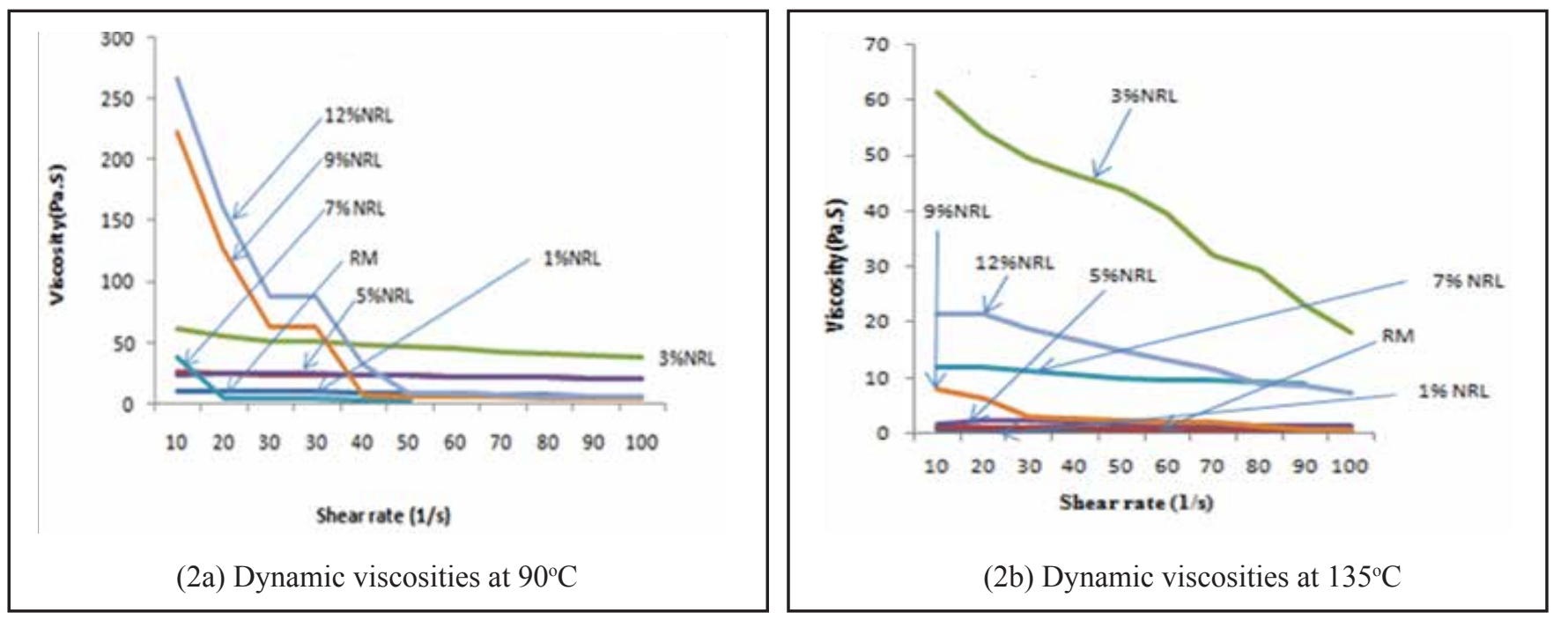

Fig. 2. Rotational viscosity profile of base and modified bitumen samples

too mobile to compact and at viscosities greater than $30 \mathrm{~Pa} . \mathrm{s}$, the material will be too stiff to allow further compaction (Read and Whiteoak, 2003).

Considering the viscosity profiles of prepared sample, bitumen-natural rubber-polyaniline blend B-3 was chosen for laboratory study due its superior properties compared to ordinary 80-100 penetration grade bitumen. It was observed that the properties of B-3 sample were also superior to 60-70 penetration grade bitumen which was recommended for paving application in Bangladesh (Afroz and Jabin, 2017).

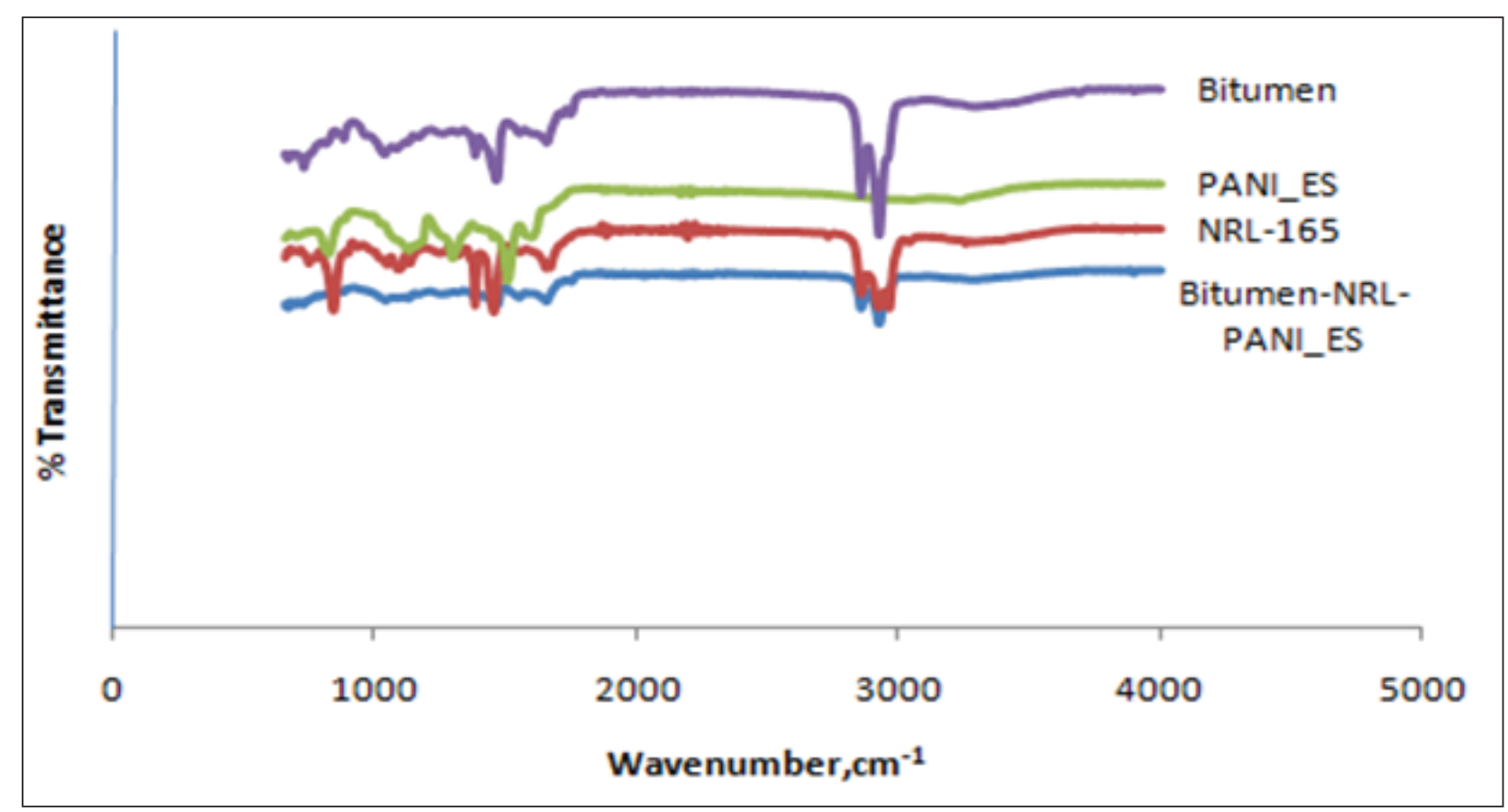

Fig. 3(a). Base line corrected spectral data of base bitumen, dried natural rubber, polyaniline emeraldine salt and selected blend of bitumen-natural rubber-polyaniline emeraldine salt 


\section{FT-IR spectral analysis}

Fig. 3(a) showed the base line corrected spectral data of 80-100 penetration grade bitumen, natural rubber latex dried at $165{ }^{\circ} \mathrm{C}$, polyaniline as emeraldine salt form and selected blend of bitumen-natural rubber-polyaniline samples.

80-100 penetration grade bitumen showed a broad absorption band at $3290 \mathrm{~cm}^{-1}$ due to O-H and/ or N-H stretching modes generated by the componant of bitumen. Absorption peak of carbonyl group of anhydride at 1741 $\mathrm{cm}^{-1}$ was present in the base bitumen that represent its oxidised state. S-O double bond stretching peak was present at $1030 \mathrm{~cm}^{-1}$ due to oxidation of bitumen (Petersen, 2009; Dony et al., 2016; Lucena et al., 2004). In figure 3(b) dried natural rubber showed a broad N-H stretching absorption band at $3293 \mathrm{~cm}^{-1}$, potentially generated from the residual ammonia after drying. Hydrocarbon absorption bands were showed at $3035 \mathrm{~cm}^{-1}$ for $\mathrm{SP}^{2} \mathrm{C}-\mathrm{H}$ stretching mode; $2960 \mathrm{~cm}^{-1}, 2919 \mathrm{~cm}^{-1}$ and $2853 \mathrm{~cm}^{-1}$ for $\mathrm{SP}^{3} \mathrm{C}-\mathrm{H}$ stretching modes. A sharp absorption band at $1647 \mathrm{~cm}^{-1}$ confirmed the presence of conjugated C-C double bond in natural rubber. No thermal oxidation peaks of natural rubber were observed after drying at $165^{\circ} \mathrm{C}$ (Ibrahim et al., 2016).

Polyaniline emeraldine salt (PANI-ES) showed absorption bands at $3231 \mathrm{~cm}^{-1}$ for N-H stretching mode, $1639 \mathrm{~cm}^{-1}$ for benzeniod ring absorption, $1445 \mathrm{~cm}^{-1}$ for $\mathrm{C}-\mathrm{C}$ double bond absorption in aromatic ring, $1289 \mathrm{~cm}^{-1}$ for C-N absorption for aromatic amine. S-O double bond absorption band of sulfate at $1123 \mathrm{~cm}^{-1}$ were also observed. Because, polyaniline emeraldine salt was synthesized at sulfuric acid media (Al-Daghman et al., 2016).

Blend of bitumen-natural rubber-polyaniline sample no. B-3 showed a broad absorption band at $3288 \mathrm{~cm}^{-1}$ generated by $\mathrm{O}-\mathrm{H}$ and/or $\mathrm{N}-\mathrm{H}$ stretching modes from bitumen and additives. Hydrocarbon bands showed at $3029 \mathrm{~cm}^{-1}$ for $\mathrm{SP}^{2}$ C-H stretching, $2922 \mathrm{~cm}^{-1}$ for $\mathrm{SP}^{3} \mathrm{C}-\mathrm{H}$ stretching and 2852 $\mathrm{cm}^{-1}$ for $\mathrm{SP}^{3} \mathrm{C}-\mathrm{H}$ stretching modes. Absorption band at 1744 $\mathrm{cm}^{-1}$ was due to presence of carbonyl group of anhydride present in bitumen. A broad band at $1648 \mathrm{~cm}^{-1}$ was generated

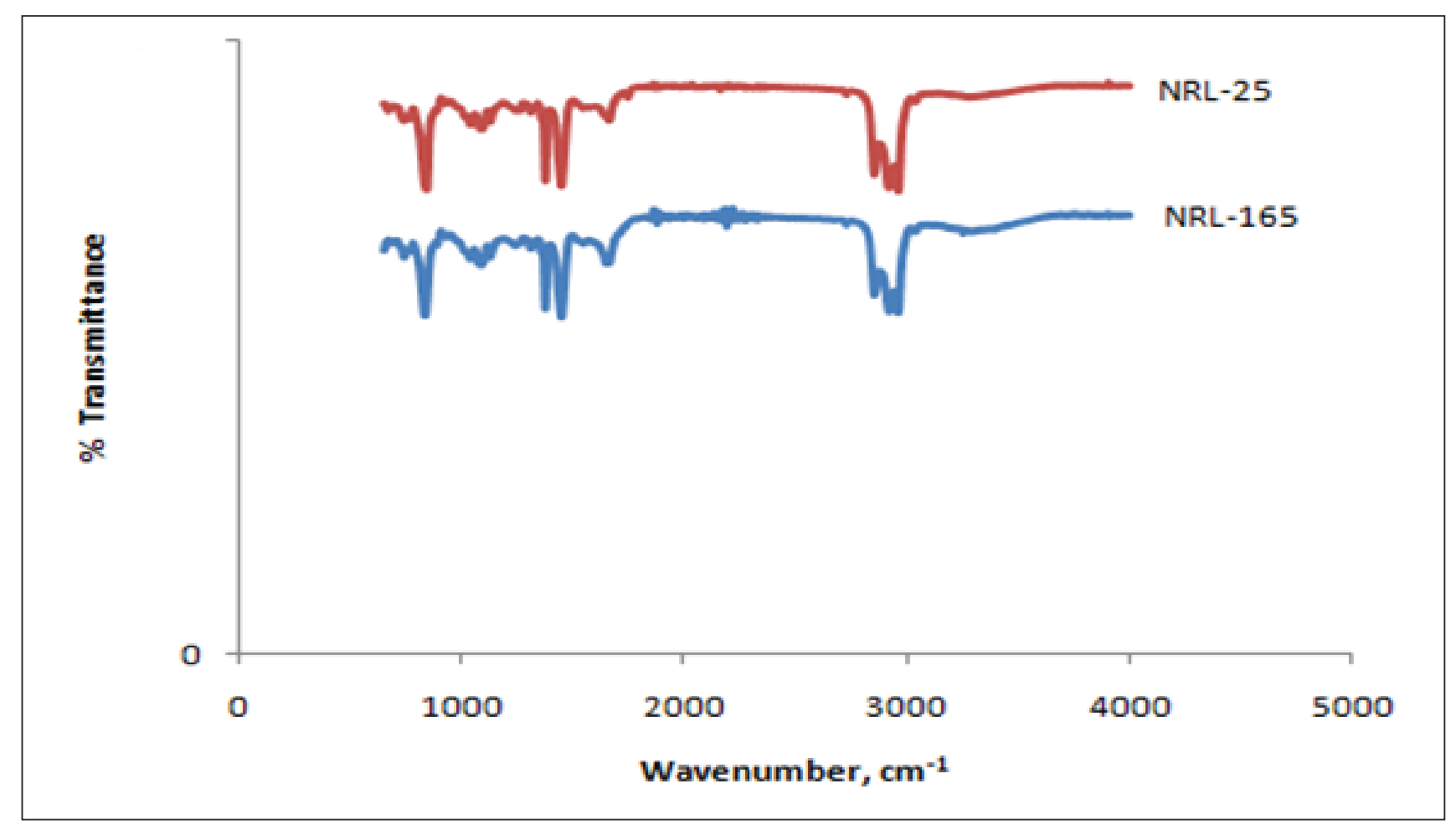

Fig. 3(b). Base line corrected spectral data of natural rubber latex dried at $25^{\circ} \mathrm{C}$ and $165^{\circ} \mathrm{C}$ 
by N-H bending modes from bitumen and contribution of additives. Absorption bands at $1456 \mathrm{~cm}^{-1}$ for $-\mathrm{CH}_{2}$ - bending,
$1377 \mathrm{~cm}^{-1}$ for $-\mathrm{CH}_{3}$ bending, $1120 \mathrm{~cm}^{-1}$ for C-O stretching and $1034 \mathrm{~cm}^{-1}$ for S-O double bond stretching were also observed.
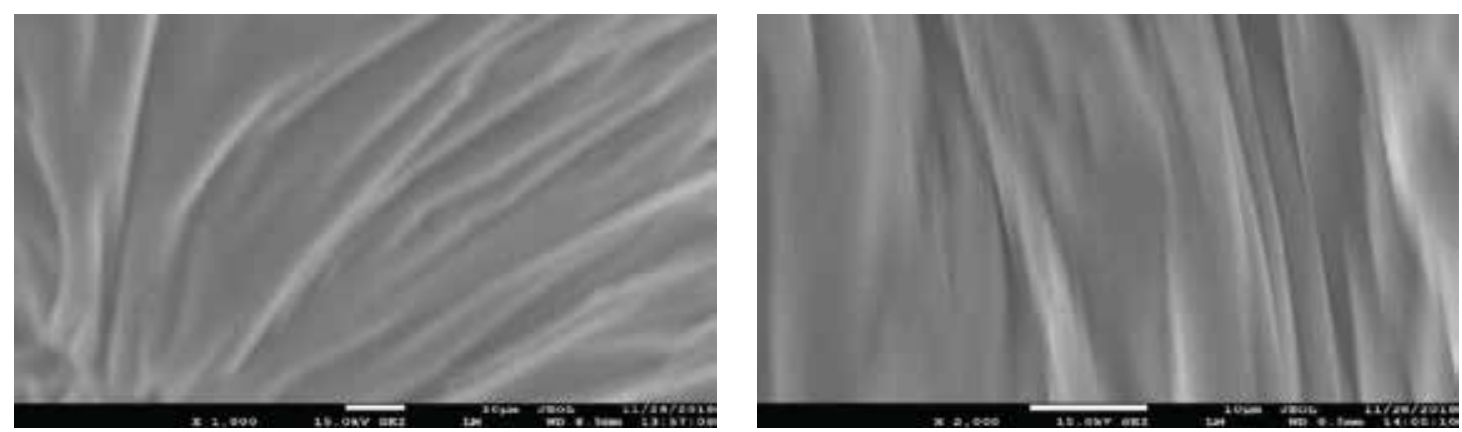

(4a) Sample No. B-1
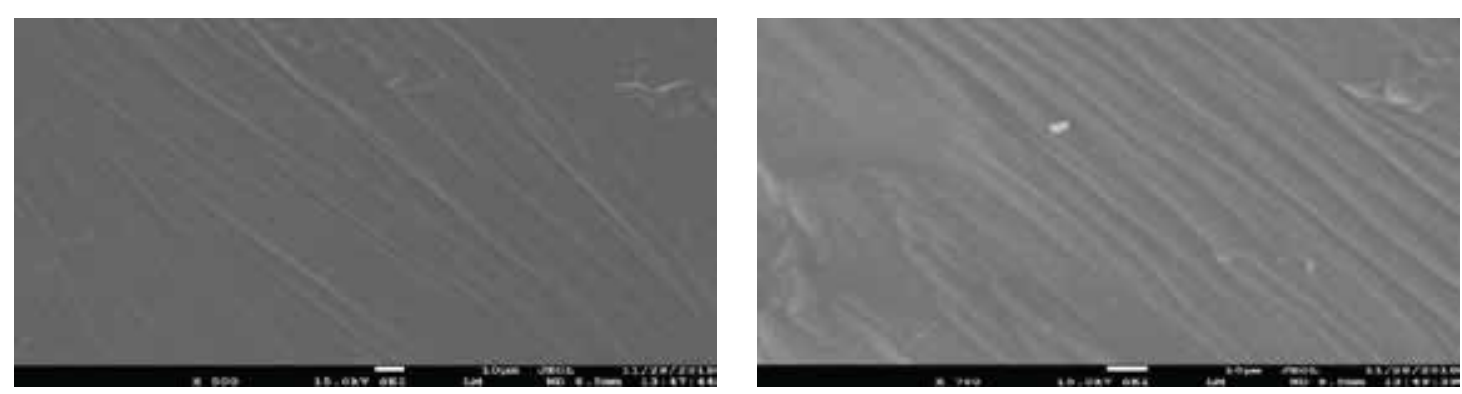

(4b) Sample No. B-2
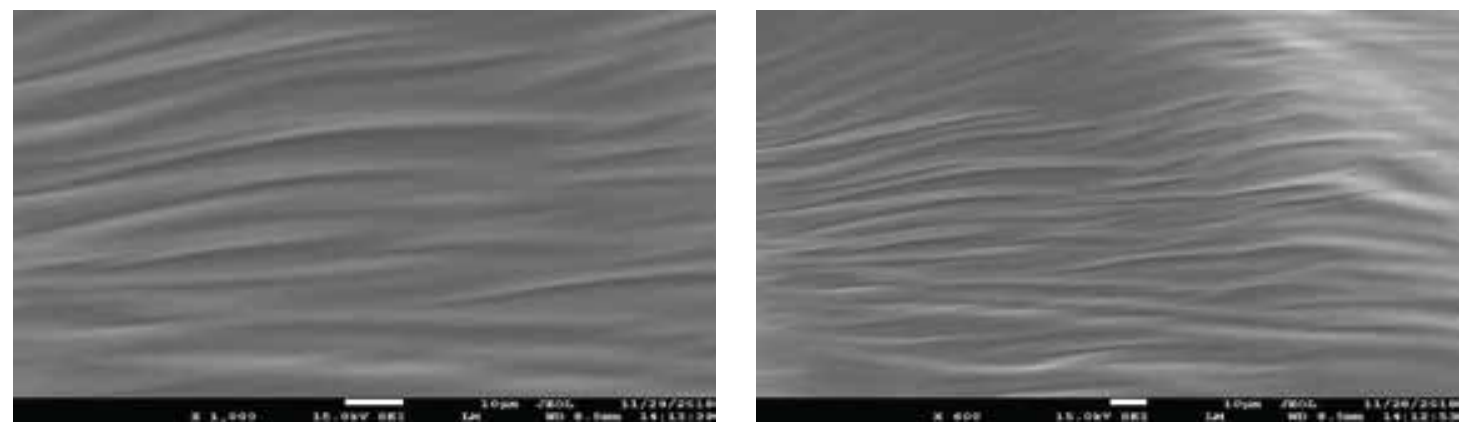

(4c) Sample No. B-3
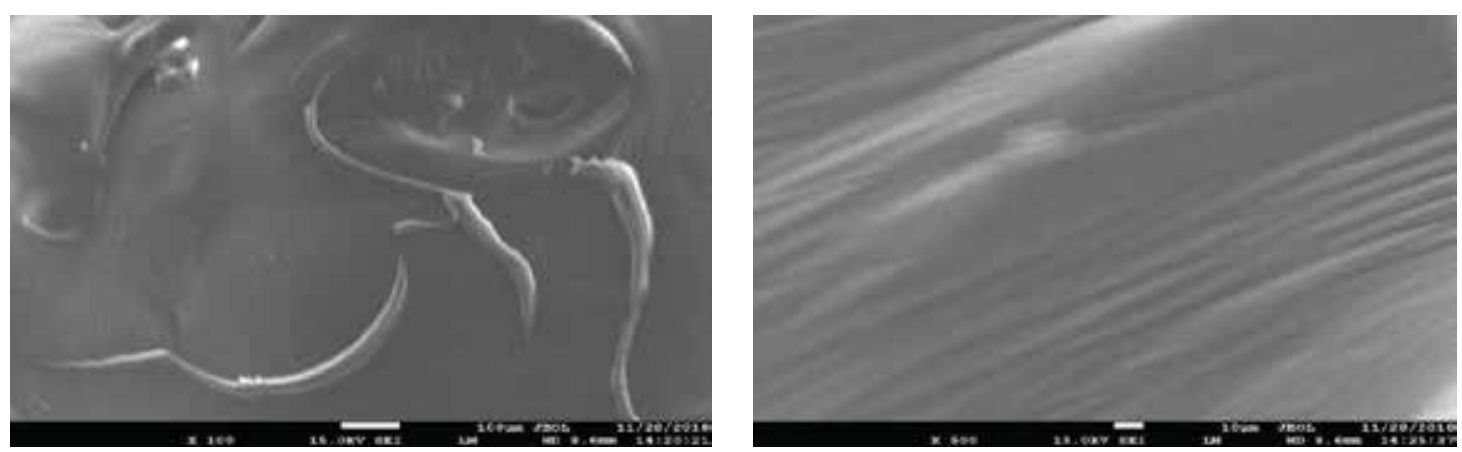

(4d) Sample No. B-4 

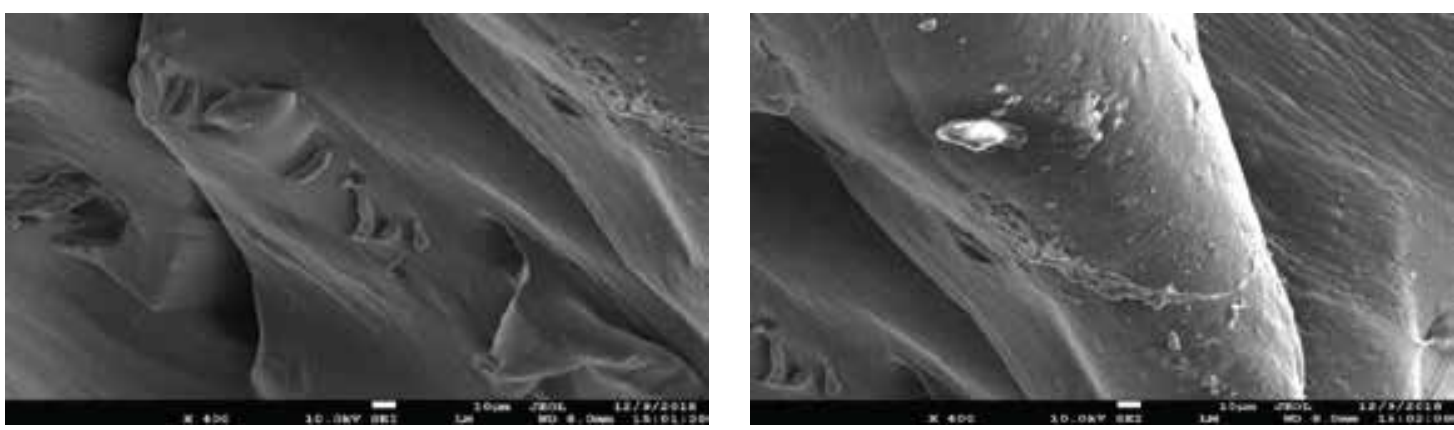

(4e) Sample No. B-5
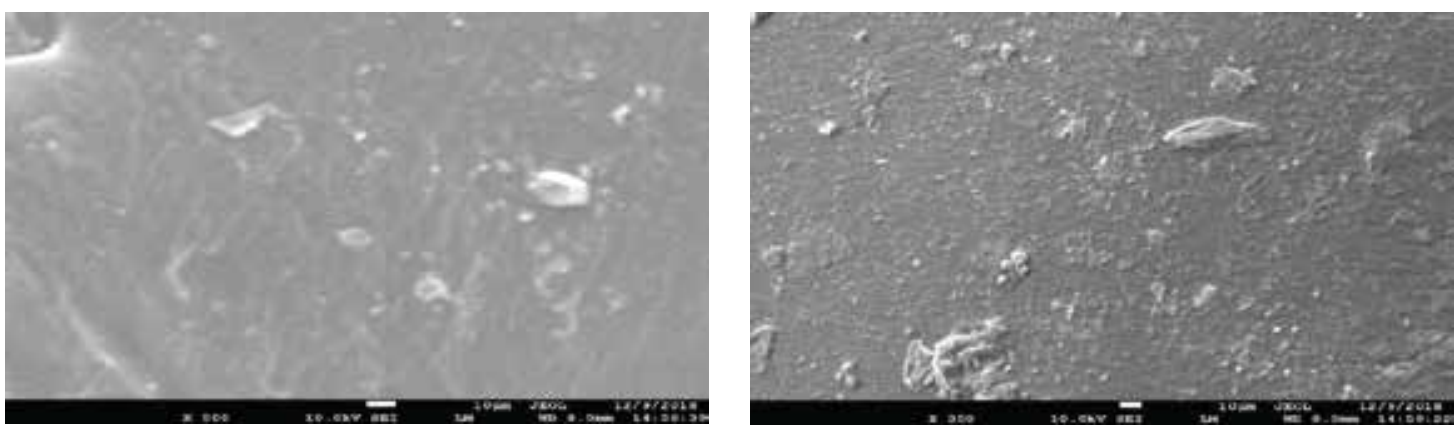

(4f) Sample No. B-6
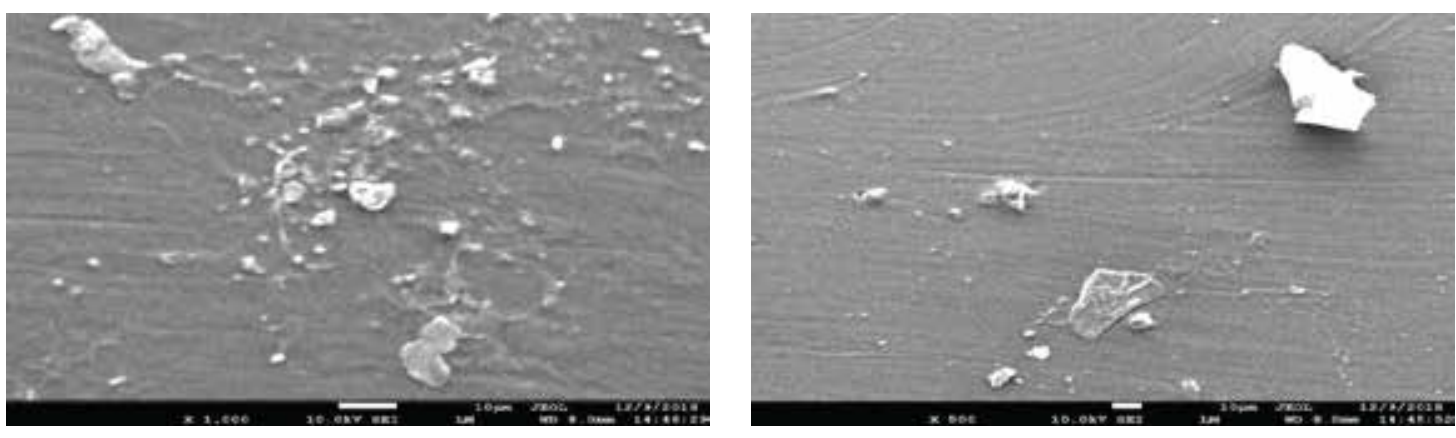

(4g) Sample No. B-7

Fig. 4. Scanning electron micrographs of B-1 to B-7 samples

Data obtained from the blend showed good mixing properties of the additives with base bitumen.

\section{Scanning electron microscopy}

Scanning electron microscopic tests were performed on all samples to evaluate mixing properties of the modifying constituents into base bitumen. Surface micrograph of modified bitumen samples showed well mixing property with base bitumen upto $3(\mathrm{w} / \mathrm{w}) \%$ natural rubber latex and $1(\mathrm{w} / \mathrm{w})$ $\%$ PANI-ES addition and then decreased gradually as indicated in the micrographs from figure 4. SEM images showed that the addition of $3(\mathrm{w} / \mathrm{w}) \%$ natural rubber and 1 (w/w)\% PANI-ES into base bitumen formed homogenous blend or compatible dispersion under applied modification conditions. Similar micrographs were obtained in previous literature (Ragab et al., 2016; Surti and Mishra, 2017).

\section{Thermal analysis}

Thermograms of 80-100 penetration grade bitumen (B-1) and selected bitumen-natural rubber-polyaniline blend (B-3) were given in fig. 5 . 


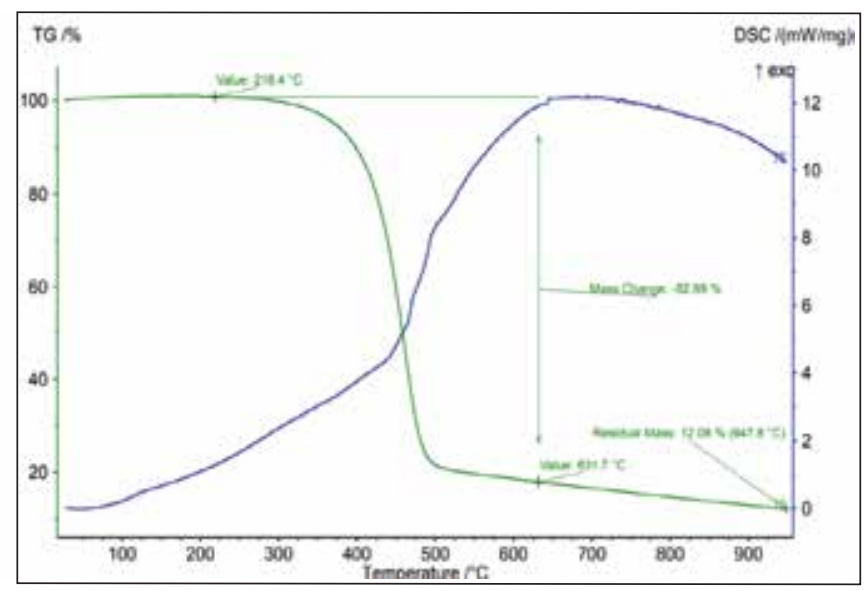

(5a) Thermogram of sample B-1

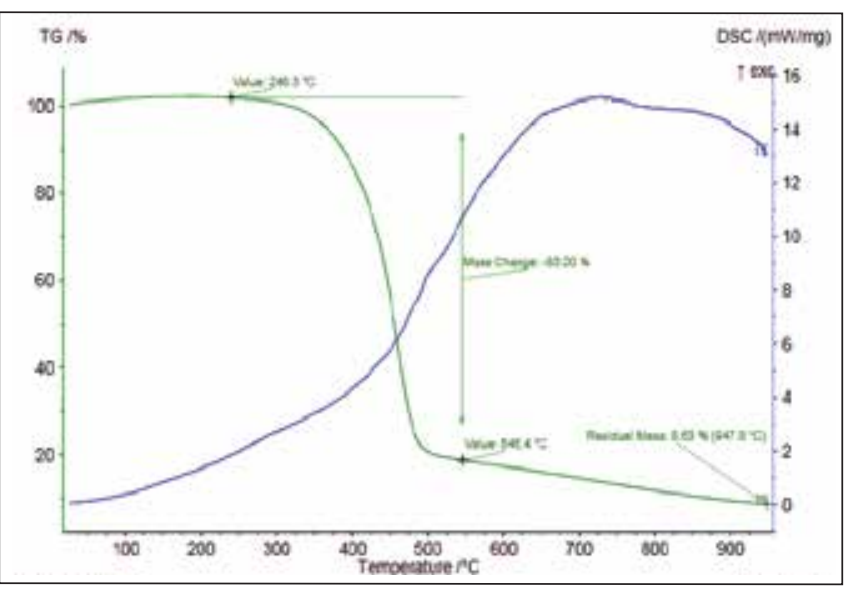

(5b) Thermogram of sample B-3

Fig. 5. Thermograms of base and selected bitumen-natural rubber-polyaniline blend samples

As shown in the figures 5(a) and 5(b), TG curve recorded the weight change against temperature. For base bitumen, no weight loss observed upto $218^{\circ} \mathrm{C}$. In case of sample B-3, no weight loss showed upto $240{ }^{\circ} \mathrm{C}$. There were no sharp endothermic or exothermic transition peaks in DSC curve at set experimental conditions. About $82 \%$ weight losses occurred in the temperature range of 250 to $550^{\circ} \mathrm{C}$. These were due to the losses of small molecule generated by breaking of unstable bonds of complex bituminous structures. So, the bitumen-natural rubber-polyaniline blend, B-3 showed better thermal stability compared to base bitumen, B-1. Similar result was reported in case of 3-10\% rubber nanoparticle modified 60-70 penetration grade bitumen (Ragab et al., 2016).

Properties of laboratory scale slab by static immersion test

\section{Slab preparation}

Two slabs (volume: $135 \mathrm{~mm}$ x $135 \mathrm{~mm}$ x $34 \mathrm{~mm}$ ) were prepared by coating the aggregates and sand (aggregate average sizes- large: $24 \mathrm{~mm}$; small: $8 \mathrm{~mm}$ and sand size: 0.5 $\mathrm{mm}$; ratios of large and small aggregates and sand were of 4:3:3) with 80-100 penetration grade bitumen (B-1) and bitumen-natural rubber-polyaniline blend (B-3) at mixing temperature $135^{\circ} \mathrm{C}$ (Table II). The asphalt mixtures $(5.75 \%$ bitumen binders were used by weight of aggregates) were then compacted at $90^{\circ} \mathrm{C}$ by laboratory compression molding machine applying 25 ton pressure. The slabs were stabilized at room temperature for $48 \mathrm{hrs}$ and submitted for static immersion test.

\section{Static immersion test}

Static immersion tests were performed with some modifications on the prepared slabs at $25^{\circ} \mathrm{C}$ for $72 \mathrm{hrs}$ and then boiled at $60^{\circ} \mathrm{C}$ for $1.5 \mathrm{hrs}$ to assess the percentage of bitumen stripped off the slabs/aggregates visually (Read and Whiteoak, 2003). It was observed that the slab prepared by bitumen-natural rubber-polyaniline blend (B-3) was stable enough compared to the slab made with 80-100 penetration grade bitumen (B-1). No significant stripping tendency was observed visually in case of modified bitumen. Structure of the slab was unchanged. The slab made with unmodified

Table II. Properties of binder bitumen used for static immersion test

\begin{tabular}{lcccccccc}
\hline $\begin{array}{l}\text { Type of } \\
\text { Bitumen }\end{array}$ & $\begin{array}{c}\text { Soft. point } \\
\left({ }^{\circ} \mathrm{C}\right)\end{array}$ & $\begin{array}{c}\text { Penetration } \\
\left(1 / 10^{\text {th }} \mathrm{mm}\right)\end{array}$ & $\begin{array}{c}\text { Penetration } \\
\text { index }\end{array}$ & $\begin{array}{c}\text { Ductility } \\
(\mathrm{cm})\end{array}$ & $\begin{array}{c}\text { Absolute } \\
\text { Viscosity at } \\
90^{\circ} \mathrm{C}(\text { Pa.s })\end{array}$ & $\begin{array}{c}\text { Absolute } \\
\text { Viscosity at } \\
135^{\circ} \mathrm{C}(\mathrm{Pa} . \mathrm{s})\end{array}$ & $\begin{array}{c}\text { Flash } \\
\text { point } \\
\left({ }^{\circ} \mathrm{C}\right)\end{array}$ & $\begin{array}{c}\text { Specific gravity } \\
@ \text { room } \\
\text { temperature }\end{array}$ \\
\hline $\mathrm{B}-1$ & 44 & 75 & -1.96 & 89 & 5.23 & 0.491 & $>230$ & 1.02 \\
$\mathrm{~B}-3$ & 64 & 58 & 2.19 & 78 & 45.38 & 31.59 & $>230$ & 0.99 \\
\hline
\end{tabular}


bitumen showed significant stripping and also cracked due to excessive softening happened. So, it can be assume that the modified bitumen showed better physical, thermal, moisture resistance and anti-stripping properties compared to unmodified 80-100 penetration grade bitumen. Result obtained has been presented in Table III and Photograph 111.

Table III. Properties of laboratory scale slab

\begin{tabular}{lcclcc}
\hline SN & $\begin{array}{c}\text { Pavement type } \\
\text { (Laboratory } \\
\text { scale slab) }\end{array}$ & $\begin{array}{c}\text { Slab volume } \\
(\mathrm{L} \mathrm{mm} \times \mathrm{W} \mathrm{mm} \times \\
\mathrm{H} \mathrm{mm})\end{array}$ & $\begin{array}{c}\text { Static immersion } \\
\text { in water for } \\
72 \mathrm{hrs} \text { at } 25^{\circ} \mathrm{C}\end{array}$ & $\begin{array}{c}\text { Static immersion in } \\
\text { boiling water for } \\
1.5 \mathrm{hrs} \text { at } 60^{\circ} \mathrm{C}\end{array}$ & $\begin{array}{c}\text { Heating in oven at } \\
50 \pm 5{ }^{\circ} \mathrm{C} \text { for } 48 \mathrm{hrs}\end{array}$ \\
\hline 1 & $\begin{array}{l}\text { Binder: B-1 } \\
80-100 \text { Pen bitumen }\end{array}$ & $\begin{array}{l}\text { Stripping happened } \\
\text { slightly }\end{array}$ & $\begin{array}{l}\text { Stripping happened } \\
\text { and cracked due to } \\
\text { softening }\end{array}$ & Softening happened \\
2 Binder: B-3 \\
modified bitumen
\end{tabular}

\section{Photograph 111. Static immersion stripping test with some modification}

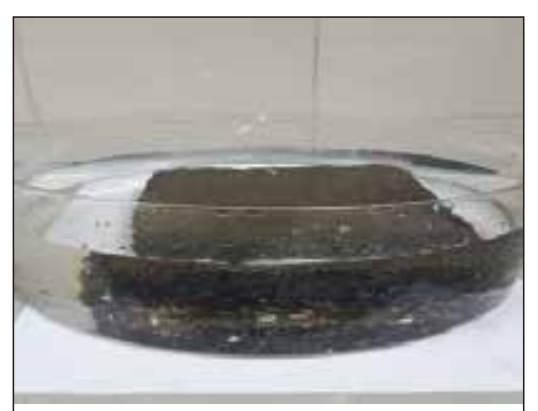

Immersion test of $80-100$ penetration grade bitumen coated slab

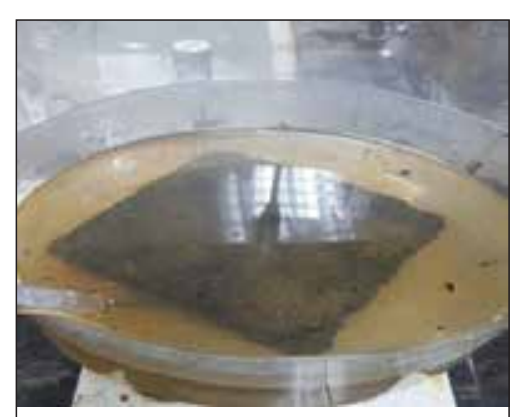

Immersion test $\left(60^{\circ} \mathrm{C}\right)$ of $80-100$ penetration grade bitumen coated slab

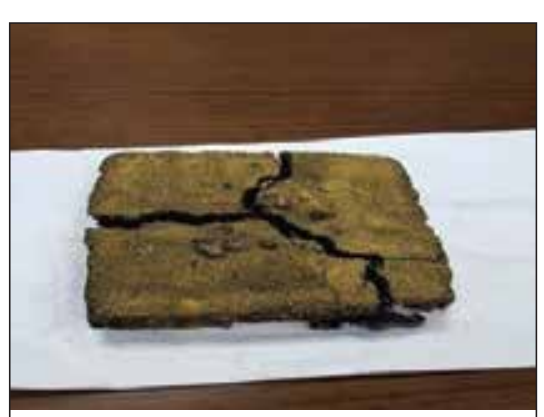

Cracked slab after immersion tests

Photograph 111(a). Static immersion stripping test for B-1 binder

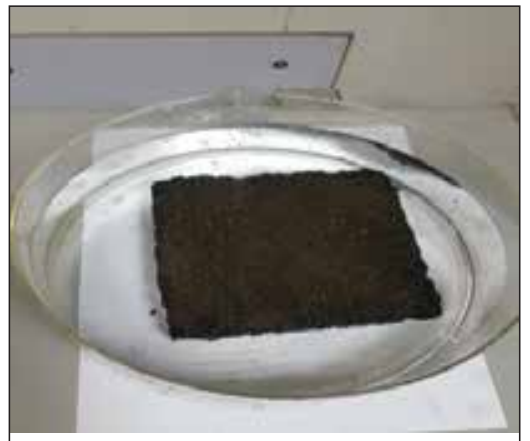

Immersion test $\left(25^{\circ} \mathrm{C}\right)$ of modified bitumen coated slab

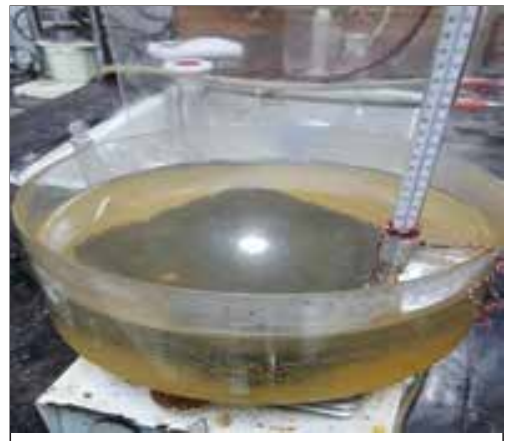

Immersion test $\left(60^{\circ} \mathrm{C}\right)$ of modified bitumen coated slab

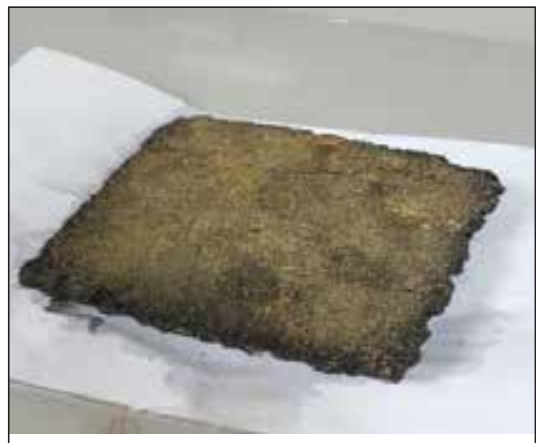

Unchanged slab after immersion tests

Photograph 111(b). Static immersion stripping test for B-3 binder 


\section{Conclusion}

Conventional 80-100 penetration grade bitumen can be modified with ammonia stabilized natural rubber latex in presence of polyaniline emeraldine salt by wet process. This modification increased the penetration index, dynamic viscosity and thermal stability of base bitumen significantly. Ductility was decreased but softening point increased with the addition of natural rubber latex. Polyaniline was reported may be for the first time as an additive for bitumen modification due to its synergistic properties, e.g. polymeric antioxidant and anti-stripping agent. Static immersion test showed greater binding or anti-stripping properties of modified bitumen with aggregates than ordinary bitumen. Special design bitumen modification equipment was used to mitigate environmental pollution and potential hazards due to evolved ammonia and other gases. So, the modification of 80-100 penetration grade bitumen with natural rubber latex and polyaniline can provide an important outlet for paving application in Bangladesh and like countries.

\section{Acknowledgement}

The authors deeply acknowledge the contribution of Dipa Islam, Senior Scientific Officer, BTRI, BCSIR, Bangladesh for SEM analysis.

\section{References}

Afroz MD and Jabin S (2017), The Most Preferable Grade of Bitumen for the Road and Weather Conditions of Bangladesh, Proceedings of Civil and Water Resources Engineering Conference, BIAM Foundation, Eskaton, Dhaka, Bangladesh, pp 1-15.

Al-Daghman ANJ, Ibrahim K, Ahmed NM and Al-Messiere MA (2016), Effect of doping by stronger ions salt on the microstructure of conductive polyaniline-ES: structure and properties, Journal of Optoelectronics and Biomedical Materials 8(4): 175-183.

Azahar NFBM, Hassan NHBA, Kadir RPJMABA, Yunus NZBM and Mahmud MZH (2016), An overview on natural rubber application for asphalt modification, International Journal of Agriculture, Forestry and Plantation 2: 212-218.

Becker Y, Méndez MP and Rodríguez Y (2001), Polymer Modified Asphalt, Vision Tecnologica 9(1): 39-50
Cui S, Blackman BRK, Kinloch AJ and Taylor AC (2014), Durability of asphalt mixtures: Effect of aggregate type and adhesion promoters, International Journal of Adhesion and Adhesives 54: 100-111.

Dessouky S, Ilias M, Park DW and Kim IT (2015), Influence of Antioxidant-Enhanced Polymers in Bitumen Rheology and Bituminous Concrete Mixtures Mechanical Performance, Advances in Materials Science and Engineering, 2015: 1-9. DOI: org/10.1155/2015/214585

Dony A, Ziyani L, Drouadaine I, Pouget S, Dumont SF, Simard D, Mouillet V, Poirier JE, Gabet T, Boulange L, Nicolai A and Gueit C (2016), MURE National Project: FTIR spectroscopy study to assess ageing of asphalt mixtures, E\&E Congress 2016, Prague, Czech Republic, DOI: org/10.14311/EE.2016.154

El-Ghaffar MAA, Shaffei KA and Abdelwahab N (2014), Evaluation of Some Conducting Polymers as Novel Antioxidants for Rubber Vulcanizates, International Journal of Polymer Science, 2014: 1-10, DOI: org/10.1155/2014/893542

Fernando MJ and Nadarajah M (1969), Use of Natural Rubber Latex in Road Construction, J. Rubb. Res. lust. Malaya 22(5): 430-440.

Fwa TF (1987), Water-Induced Distress in Flexible Pavement in a Wet Tropical Climate, Transportation research record 1121, Onlinepubs/ trr/1987/ 1121/1121-009.pdf

Hınıslığlu S (2011), Optimization of the temperature susceptibility of bitumen modified with waste tire rubber by taguchi method, http://dergipark.gov.tr/ download/article-file/68405

Ibeagia UM, Okerekeb SOE, Okpareke OC and Ukohac PO (2012), Studies On The Modifications Of Asphalt Binder Using Some Selected Polymers, Int. J. Chem. Sci. 10(4): 2048-2056.

Ibrahim S, Othman N and Ismail H (2016), Degradation of natural rubber latex, https://www.researchgate.net/ publication/318837643 
Kishore KSN and Gottala A (2015), A Study on Effect of Addition of Natural Rubber on the Properties of Bitumen \& Bituminous Mixes; International Journal of Science Technology \& Engineering 2(1): 206-212.

Krishnapriya MG (2015), Performance evaluation of natural rubber modified bituminous mixes, Journal of Civil, Structural, Environmental, Water resources and Infrastructure Engineering Research 5(1): 1-12.

Lucena MCC, Soares SA and Soares JB (2004), Characterization and Thermal Behavior of Polymer-Modified Asphalt, Materials Research 7(4): 529-534.

Mashaan NS, Ali AH, Karim MR and Abdelaziz M (2011), Effect of crumb rubber concentration on the physical and rheological properties of rubberised bitumen binders, International Journal of the Physical Sciences 6(4): 684-690.

Mashaan NS, Ali AH, Karim MR and Abdelaziz M (2014), A Review on Using Crumb Rubber in Reinforcement of Asphalt Pavement, The Scientific World Journal, 2014: 1-21. DOI: org/10.1155/2014/214612

Petersen JC (2009), A review of the fundamentals of asphalt oxidation; Transp. Res. Circ. E-C1 40: 1-78, http://onlinepubs. trb.org/ onlinepubs/ circulars/ec140.pdf

Pristi DL (2013), Recycled Tyre Rubber Modified Bitumens for road asphalt mixtures: A literature review, Construction and Building Materials 49: 863-881, DOI: org/10.1016/j. conbuildmat. 2013.09.007

Pyshyev S, Gunka V, Grytsenko Y and Bratychak M (2016), Polymer modified bitumen: Review; Chemistry \& Chemical Technology 10(4s): 631-636.

Ragab AA, Kandil UF, Shafie ME, Farag RK, Saleh AMM and El-Kafrawy AF (2016), Novel modification of soft asphalt for use in infrastructure applications, Material Science 14(4): 109-118.
Read J and Whiteoak D (2003), The Shell Bitumen Handbook, $5^{\text {th }}$ Ed., Thomas Telford Ltd, London, p 460 .

Remišová E, Zatkaliková V and Schlosser F (2016), Study Of Rheological Properties Of Bituminous Binders In Middle and High Temperatures, De Gruyter 12(1): 13-20, DOI: 10.1515/Cee-2016-0002

Rossi CO, Teltayev B and Angelico R (2017), Adhesion Promoters in Bituminous Road Materials: A Review, Appl. Sci. 7(5): 1-10. DOI: 10.3390/app7050524

Shafabakhsh GH, Sadeghnejad M and Sajed Y (2014), Case study of rutting performance of HMA modified with waste rubber powder, Case Studies in Construction Materials 1: 69-76, DOI: org/10.1016/j. cscm. 2014.04.005

Shafii MA, Veng CLY, Rais NM and Latif AA (2017), Effect of Blending Temperature and Blending Time on Physical Properties of NRL-Modified Bitumen, International Journal of Applied Engineering Research 12(13): 3844-3849.

Smith RB (2004), Forensic Investigation of Pavement Failures, Ph.D. Thesis, pp 1-433, University of Southern Queensland Faculty of Engineering and Surveying, Australia, https://eprints.usq.edu.au/94/1/ Richard SMITH-2004.pdf

Subhy A, Prestia DL and Airey G (2016), Rubberised bitumen manufacturing assisted by rheological measurements, Road Materials and Pavement Design 17(2): 290-310, DOI: 10.1080/14680629. 2015. 1079549

Surti K and Mishra PCB (2017), Evaluating the Effect of Modified Bitumen after Short-Term Aging using FTIR Spectroscopy \& SEM, International Journal for Research in Applied Science \& Engineering Technology 5(V): 222-227.

Willway T, Baldachin L, Reeves S, Harding M, McHale M and Nunn M (2008), The effects of climate change on highway pavements and how to minimise them: Technical report, p 124, https://trl.co.uk/ reports/PPR184 
Yener E and Hınıslıoğlu S (2014), Effects of exposure time and temperature in aging test on asphalt binder properties, International Journal of Civil And Structural Engineering 5(2): 112-124, DOI: 10.6088/ ijcser.2014050011

Zailan FD, Chen RS, Ahmad S, Shahdan D, Khairunnisa and Baharin W (2017), Influence of Processing Conditions on Mechanical Behaviours of Thermoplastic Natural Rubber/ Polyaniline Blend,
Journal of Mechanical Engineering 3(1): 225-235.DOI: 10.1063/1.4966815

Žilinjtơ L, Motiejnjnas A, Kleizienơ R, Gribulis G and Kravcovas I (2016), Temperature and moisture variation in pavement structures of the test road, Transportation Research Procedia 14: 778-786. DOI: 10.1016/j.trpro.2016.05.067 